\title{
Rancang Bangun Aplikasi Permodelan Sambungan Kayu (Wood Joint) dengan Objek 3D Berbasis Android
}

\author{
Putu Andi Prayoga, Putu Wira Buana, A. A. K. Agung Cahyawan Wiranatha \\ Program Studi Teknologi Informasi Universitas Udayana \\ Bukit Jimbaran, Bali, Indonesia, telp. (0361) 701806 \\ e-mail: putuandiprayoga@gmail.com , wbhuana@it.unud.ac.id , agung.cahyawan@unud.ac.id
}

\begin{abstract}
Abstrak
Kayu merupakan bahan konstruksi yang banyak digunakan dalam industri mebel. Produk mebel tersusun atas sambungan kayu yang saling terhubung sehingga dapat membentuk suatu objek. Wood joint adalah keterampilan untuk menghubungkan dan menguatkan bagian dari kontruksi kayu dengan cara pemotongan tertentu pada ujung atau sisi dari bagian kontruksi kayu. Informasi mengenai model sambungan kayu saat ini umumnya hanya disajikan dalam bentuk gambar dua dimensi yang dimuat pada e-book ataupun media cetak, sehingga kurang menarik untuk dipelajari. Keterbatasan media informasi yang ada dapat diatasi dengan memvisualkan informasi mengenai model sambungan kayu melalui objek tiga dimensi. Informasi sambungan kayu dirancang ditampilkan melalui objek tiga dimensi beserta animasi menggunakan Unity3D. Aplikasi mobile berbasis Android yaitu WoodVenture dikembangkan pada penelitian ini yang diharapkan dapat memberikan pembelajaran membuat mebel untuk orang awam dan membantu pengguna mengetahui model sambungan kayu pada perancangan kerajinan mebel. Aplikasi WoodVenture memberikan pengetahuan tentang 40 model sambungan kayu melalui fitur animasi penyambungan model 3D. Aplikasi yang dihasilkan secara tidak langsung mengedukasi pengguna untuk mengetahui jenis model sambungan kayu yang dibuktikan melalui hasil kuesioner, yaitu sebesar 70\% responden paham terkait konten yang terdapat pada Aplikasi WoodVenture.
\end{abstract}

Kata Kunci : Wood Joint, Sambungan Kayu, Mebel, Unity3D, Android

\begin{abstract}
Wood is a construction material widely used in the furniture industry. Furniture products are composed of interconnected wooden connections that can form an object. Wood joint is a skill to connect and strengthen part of wood construction by cutting certain at the end or side of wood construction part. Information on current wooden connection models is generally only presented in the form of two-dimensional images contained in e-books or print media, which makes it less interesting to learn. The limitations of existing information media can be overcome by visualizing information on wooden connection models through three-dimensional objects. Wood designed connection information displayed via a three-dimensional object with animation using the Unity3D. Android-based mobile application that is WoodVenture developed in this research are expected to provide learning for lay people to make furniture and helps users to know the connection models design of timber crafts furniture. WoodVenture provide applications knowledge about 40 wooden connection model through animated feature connecting models. The resulting application indirectly educate users to know the types of connection model wood evidenced through the results of the questionnaire, that is $70 \%$ of respondents understand the related content contained in WoodVenture applications.
\end{abstract}

Keywords : Wood Joint, Wood Connection, Furniture, Unity 3D, Android

\section{Pendahuluan}

Kayu merupakan bahan kontruksi yang banyak digunakan dalam industri mebel. Berbagai produk mebel tersusun atas sambungan kayu yang saling terhubung sehingga dapat membentuk suatu objek. Teknik sambungan kayu atau sering disebut dengan wood joint adalah keterampilan untuk menghubungkan dan menguatkan bagian dari kontruksi kayu satu sama

Rancang Bangun Aplikasi Permodelan Sambungan Kayu (Wood Joint) dengan Objek 3D $\quad 162$ Berbasis Android

(Putu Andi Prayoga) 
lain dengan cara pemotongan tertentu pada ujung atau sisi dari bagian kontruksi kayu [1]. Informasi mengenai sambungan kayu umumnya hanya disajikan dalam bentuk gambar dua dimensi yang dimuat pada e-book ataupun media cetak, sehingga kurang menarik untuk dipelajari. Merujuk pada terbatasnya informasi yang didapat mengenai permodelan sambungan kayu, menyebabkan kurangnya pengetahuan tentang macam-macam model sambungan yang ada. Suatu sarana teknologi sangat diperlukan untuk membuat media informasi menjadi lebih interaktif dan dapat dijadikan sebagai media pembelajaran membuat mebel untuk orang awam, salah satunya dengan memanfaatkan teknologi smartphone.

Smartphone merupakan salah satu teknologi yang sedang berkembang di seluruh dunia saat ini [2]. Teknologi smartphone sangat populer karena kehadirannya yang memiliki beragam fitur menarik di dalamnya, meliputi multimedia, games, hingga jaringan internet [3]. Fitur multimedia dapat diterapkan dalam aplikasi smartphone pada bidang mebel, salah satunya dengan pembuatan aplikasi media pembelajaran tentang permodelan sambungan kayu yang dibuat dengan objek 3D ke dalam perangkat smartphone berbasis Android. Android menyediakan platform terbuka bagi para pengembang dalam menciptakan suatu aplikasi yang dapat digunakan di berbagai perangkat [4]. Android memiliki keuntungan salah satunya bersifat open source, yang berarti sumber kodenya bebas untuk dipelajari, diubah, ditingkatkan dan disebarluaskan oleh para developer.

Penelitian sebelumnya yang membahas terkait pembuatan aplikasi media pembelajaran berbasis smartphone Android adalah penelitian yang dilakukan oleh I Nyoman Artha Wijaya, A.A.K. Oka Sudana, \& Putu Wira Buana yang berjudul "Aplikasi Pembelajaran Membuat Ketupat dengan Animasi Model 3D Berbasis Android" [5]. Penelitian aplikasi pembelajaran membuat ketupat membahas mengenai perancangan aplikasi yang mampu menampilkan cara pembuatan ketupat dengan animasi tradisional dengan model 3D. Aplikasi dibuat pada platform Android dengan Unity sebagai main software pembuatnya. Penelitian yang dilakukan oleh Wamiliana, Dian Kurniasari, \& Jevri Setia Nugraha yang berjudul "Pembuatan Media Pembelajaran Pengenalan Tata Surya dan Exoplanet dengan Menggunakan Unity untuk Sekolah Menengah Pertama" [6] juga menjelaskan tentang pembuatan media pembelajaran dengan menggunakan multimedia interaktif terkait topik tentang tata surya. Penelitian ini menerangkan bahwa pada sekolah menengah pertama umumnya masih menggunakan multimedia interaktif yang berbasis 2D dan hanya memberi topik tentang tata surya. Penelitian karya Wamiliana, Dian Kurniasari, \& Jevri Setia Nugraha memberikan inovasi yaitu pengembangan dengan menyajikan multimedia interaktif yang berisi topik tentang tata surya dan exoplanet dengan multimedia interaktif animasi berbasis 3D.

Penelitian terkait aplikasi membuat ketupat dan aplikasi pembelajaran tata surya membuktikan bahwa media pembelajaran yang dikemas dalam konsep model 3D dapat meningkatkan efektifitas dan membangkitkan minat belajar [5,6]. Aplikasi pembelajaran model sambungan kayu yaitu WoodVenture merupakan solusi pada penelitian ini yang diharapkan dapat memberikan pembelajaran membuat mebel untuk orang awam dan membantu pengguna mengetahui model sambungan kayu pada perancangan kerajinan mebel. Aplikasi WoodVenture dirancang dapat menampilkan 40 model sambungan kayu (wood joint) dalam bentuk model 3D disertai dengan animasi, dan terdapat menu pembelajaran yang memuat pengetahuan tentang wood joint, jenis perkakas yang digunakan, serta informasi jenis-jenis kayu yang biasa digunakan dalam kerajinan mebel untuk menambah wawasan masyarakat awam.

\section{Metodologi Penelitian}

Metodologi penelitian Rancang Bangun Aplikasi Permodelan Sambungan Kayu (Wood Joint) dengan Objek 3D Berbasis Android menggunakan metode DSRM (Design Science Research Method) yang terdiri dari 8 tahapan yaitu melakukan studi literatur dengan mencari teori-teori penunjang pembuatan aplikasi melalui (buku, jurnal, artikel dan laporan penelitian), identifikasi masalah, penentuan tujuan, perancangan solusi, demo, pengujian, pembahasan, dan kesimpulan.

\subsection{Gambaran Umum Aplikasi}

Aplikasi Permodelan Sambungan Kayu (Wood Joint) dengan Objek 3D Berbasis Android yaitu WoodVenture merupakan suatu aplikasi pembelajaran yang menampilkan informasi mengenai jenis-jenis sambungan kayu dengan bentuk objek tiga dimensi. Jenis-jenis sambungan kayu inilah salah satu poin utama pada aplikasi ini, karena peran sambungan kayu dirasa sangat penting dalam membentuk suatu produk mebel. 


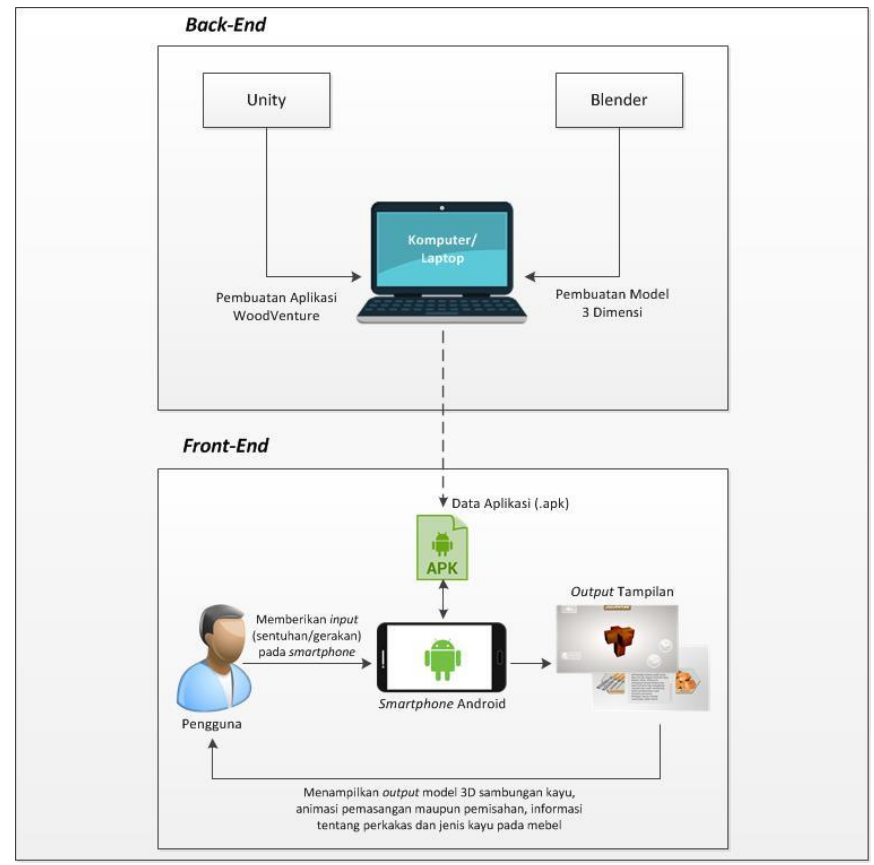

Gambar 1. Gambaran Umum Aplikasi

Gambar 1 menunjukkan Gambaran Umum Sistem Aplikasi WoodVenture yang diterapkembangkan. Bagian back-end pada gambaran umum sistem terbagi menjadi dua proses, yaitu proses pertama pembuatan modeling 3D menggunakan software Blender, yang kemudian pada proses kedua dirancang menjadi sebuah aplikasi berbasis Android menggunakan software Unity. Aplikasi yang telah berhasil dibuat, disimpan menjadi format .apk dan dapat dipasang pada smartphone Android. Bagian front-end menjelaskan bagaimana pengguna menggunakan aplikasi. Pengguna meng-install Aplikasi WoodVenture pada smartphone Android, dan memberikan input berupa sentuhan pada aplikasi untuk pemilihan menu, serta memberikan gesture pada aplikasi seperti drag, scale, maupun rotate untuk melakukan transformasi pada objek 3D model sambungan. Tampilan output dari Aplikasi WoodVenture, menyajikan beragam model sambungan kayu berbentuk objek 3D, dan informasi mengenai jenis perkakas serta jenis kayu untuk menambah wawasan pengguna di bidang mebel khususnya pada penerapan sambungan kayu.

Aplikasi Permodelan Sambungan Kayu WoodVenture terdiri dari beberapa scene aplikasi yaitu Scene Model, Ensiklopedia, Pengaturan, Galeri, Tentang, dan Keluar. Gambar 2 menggambarkan aktivitas sistem Aplikasi WoodVenture secara umum. 


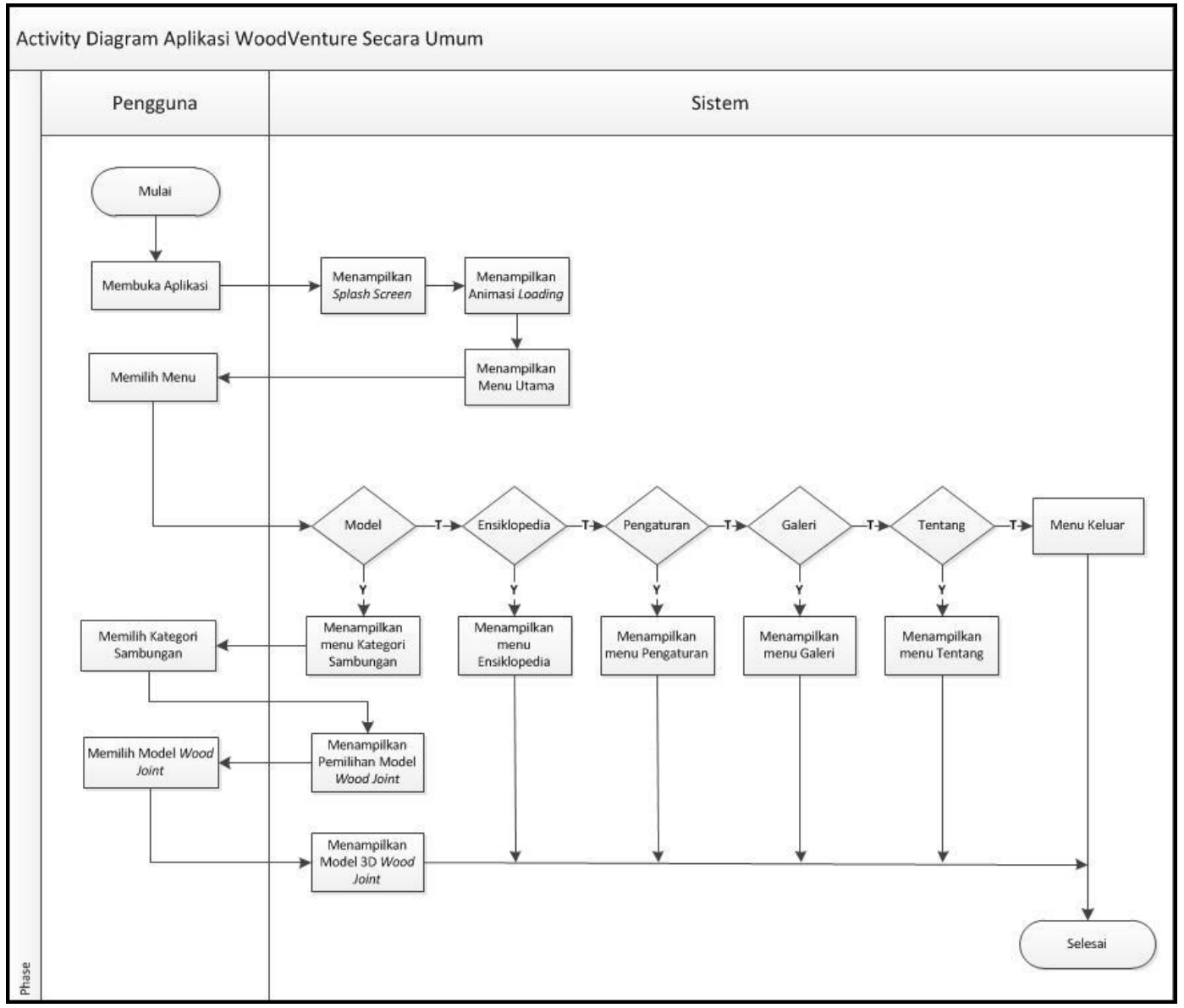

Gambar 2. Activity Diagram Aplikasi WoodVenture Secara Umum

Gambar 2 merupakan Activity Diagram Aplikasi Secara Umum. Pengguna membuka Aplikasi WoodVenture yang ter-install pada smartphone Android. Aplikasi WoodVenture menampilkan Splash Screen, kemudian Aplikasi WoodVenture menampilkan animasi Loading untuk mempersiapkan tampilan halaman awal. Animasi Loading menampilkan progress bar yang berfungsi untuk memuat seluruh scene. Aplikasi WoodVenture menampilkan halaman awal yang berisi pilihan enam menu utama, yaitu Menu Model, Ensiklopedia, Pengaturan, Galeri, Tentang, dan Keluar. Pengguna memilih menu yang terdapat pada halaman awal, jika pengguna memilih Menu Model, maka aplikasi menampilkan Scene Kategori Sambungan, jika memilih Menu Ensiklopedia, maka aplikasi menampilkan Scene Ensiklopedia, jika memilih Menu Pengaturan, maka aplikasi menampilkan Scene Pengaturan, jika memilih Menu Galeri, maka aplikasi menampilkan Scene Galeri, jika memilih Menu Tentang, maka aplikasi menampilkan Scene Tentang dan jika memilih Menu Keluar, maka aplikasi tertutup. Scene Kategori Sambungan adalah scene untuk memilih kategori jenis sambungan, antara lain sambungan tanpa pasak dan sambungan tanpa pasak. Pengguna memilih salah satu diantara dua jenis kategori sambungan, dan selanjutnya aplikasi menampilkan jenis model sambungan sesuai dengan kategori yang dipilih. Pengguna memilih model sambungan, dan aplikasi menampilkan model 3D sambungan kayu secara langsung, disertai dengan adanya fitur drag, scale, rotate dan animasi yang dapat dilakukan oleh pengguna aplikasi.

\section{Kajian Pustaka}

Beberapa teori penunjang digunakan sebagai dasar acuan dalam pembuatan Rancang

Bangun Aplikasi Permodelan Sambungan Kayu (Wood Joint) dengan Objek 3D Berbasis Android. Teori penunjang yang disertakan yaitu materi penunjang dan aplikasi pendukung yang digunakan dalam pembuatan aplikasi. 


\subsection{Wood Joint}

Wood joint adalah keterampilan untuk menghubungkan dan menguatkan bagian dari kontruksi kayu satu sama lain dengan cara pemotongan tertentu pada ujung atau sisi dari bagian kontruksi kayu. Wood joint merupakan tempat dimana dua buah kontruksi kayu bergabung menjadi satu untuk mendukung dalam pembentukan suatu kontruksi permanen [7]. Berbagai macam metode sambungan dalam teknik sambungan kayu banyak dikembangkan pada beberapa negara. Metode yang ada sangat bervariasi dan dapat dikombinasikan sesuai dengan kebutuhan. Kekuatan sambungan kayu diperoleh dari jenis ikatan sambungan yang ada dan juga kekuatan perekat yang digunakan.

\subsection{Permodelan Tiga Dimensi}

Pemodelan adalah membentuk suatu benda-benda atau objek dengan cara mendesain objek sehingga terlihat seperti hidup. Proses permodelan tiga dimensi, sesuai dengan objek dan basisnya secara keseluruhan dikerjakan di komputer. Konsep dan proses desain, keseluruhan objek dapat diperlihatkan secara tiga dimensi, sehingga banyak yang menyebut hasil ini sebagai pemodelan tiga dimensi (3D modelling). Blender mendukung penciptaan pemodelan 3D, rigging, animasi, simulasi, rendering, compositing, motion tracking, editing video serta produksi game [8]. Proses pemodelan 3D membutuhkan perancangan yang dibagi dengan beberapa tahapan untuk pembentukannya, yaitu objek yang ingin dibentuk sebagai objek dasar, metode pemodelan objek 3D, pencahayaan dan animasi gerakan objek sesuai dengan urutan proses yang dilakukan.

\subsection{Android}

Android adalah sebuah software untuk perangkat mobile yang mencakup sistem operasi, middleware dan aplikasi kunci. Android SDK menyediakan alat dan application programming interface (API) yang diperlukan untuk mulai mengembangkan aplikasi pada platform Android menggunakan bahasa pemrograman Java [9]. Android dikembangkan dan dirilis pada Tahun 2007 oleh Open Handset Allience (OHA) yaitu aliansi yang bertujuan untuk mengembangan suatu open standard untuk perangkat mobile. Android telah diakuisisi oleh Google dan dikembangkan bersama dengan Open Handset Allience. Android juga disertai oleh SDK (Software Development Kit) dan API (Application Programming Interface) yang digunakan untuk mengembangkan aplikasi pada platform Android menggunakan berbagai bahasa pemrograman seperti Java (native), C\#, HTML, CSS, Javascript, dan sebagainya.

\subsection{Unity 3D}

Unity merupakan game engine yang dapat mempermudah game designer dalam membuat game. Bahasa pemrograman yang digunakan pada Unity adalah Javasciprt, C\# dan Boo. Pembuatan game dengan Unity dilakukan dengan mendefinisikan setiap level sebagai sebuah scene yang merupakan area akses pemain ketika user memainkan game [10]. Unity merupakan game engine yang mudah digunakan, dalam setiap objek mempunyai variabel yang harus dimengerti supaya dapat membuat game yang berkualitas. Kelebihan Unity3D adalah kemampuan dalam mengontrol berbagai objek dalam game atau aplikasi dengan mudah.

\section{Hasil dan Pembahasan}

Hasil dan pembahasan berisikan tentang pembahasan dari sistem yang telah dirancang, pengujian sistem dan analisis hasil yang didapat setelah melakukan pengujian terhadap aplikasi WoodVenture.

\subsection{Tampilan Aplikasi Permodelan Sambungan Kayu WoodVenture}

Sub bab 4.1 membahas mengenai tampilan aplikasi secara keseluruhan pada scene yang ada. Tampilan awal aplikasi WoodVenture memiliki enam buah button dengan fungsi berbeda-beda. Tampilan dari halaman menu utama dari aplikasi WoodVenture ditunjukkan pada Gambar 3. 


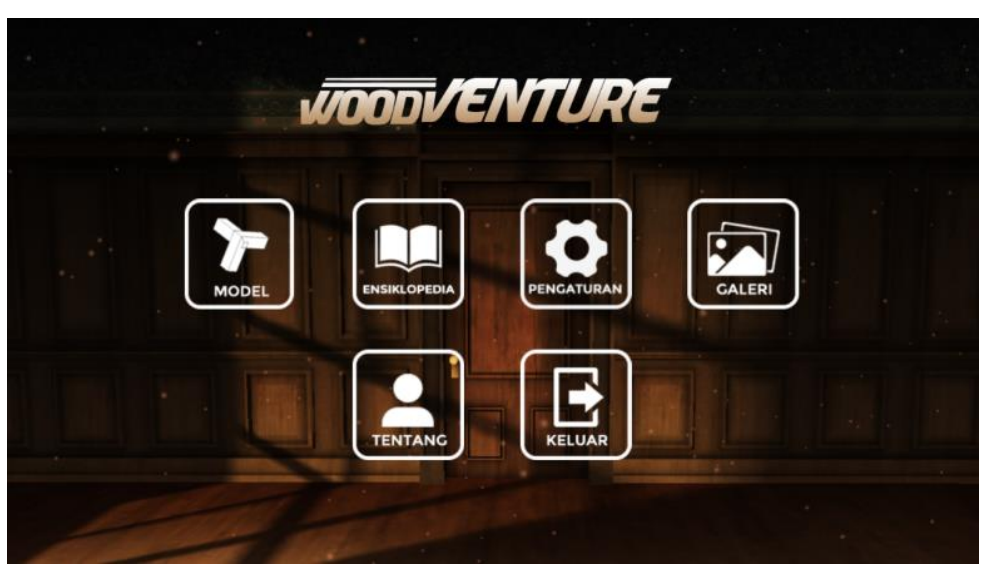

Gambar 3. Tampilan Menu Utama

Gambar 3 merupakan Tampilan Menu Utama pada Aplikasi WoodVenture yang berisikan gambar background ruangan yang didominasi dengan tekstur kayu berwarna coklat agar terlihat sesuai dengan tema dari aplikasi. Menu utama memiliki enam buah button dengan fungsi berbeda-beda. Button Model mengantarkan pengguna menuju Halaman Kategori Sambungan, Buton Ensiklopedia mengantarkan pengguna menuju Halaman Ensiklopedia, Button Pengaturan mengantarkan pengguna menuju Halaman Pengaturan Suara, Button Galeri mengantarkan pengguna menuju Halaman Galeri Mebel, Button tentang mengantarkan pengguna menuju Halaman Tentang Aplikasi, dan Button Keluar mengantarkan pengguna untuk menutup aplikasi.

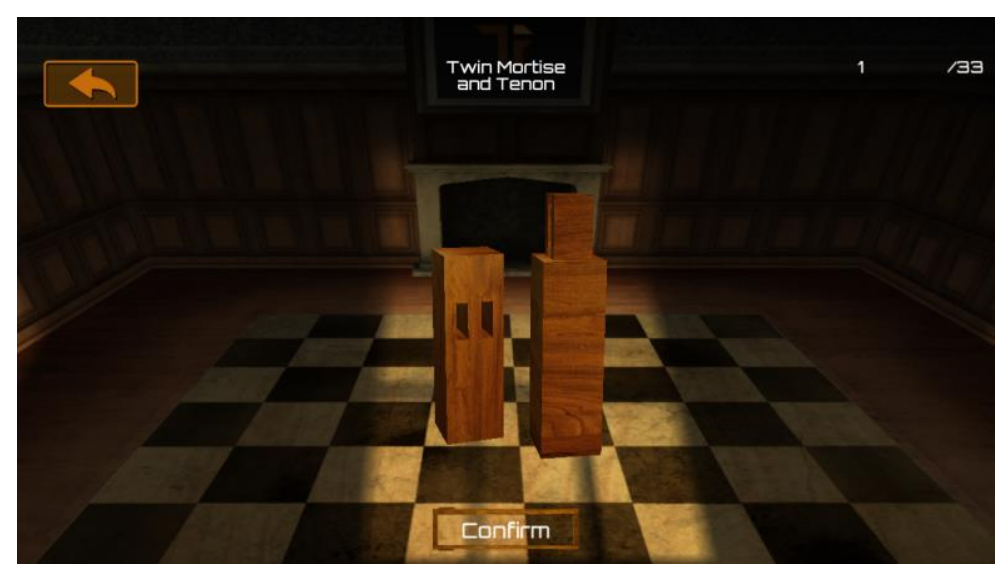

Gambar 4. Tampilan Pemilihan Model Sambungan

Gambar 4 merupakan Tampilan Pemilihan Model Sambungan yang terdapat pada Aplikasi WoodVenture. Pengguna dapat memilih model sambungan dengan cara menyentuh layar dan menggeser ke kanan ataupun ke kiri untuk melihat list pilihan sambungan yang tersedia. Button Back yang terdapat pada Tampilan Scene Pemilihan Model Sambungan digunakan untuk kembali ke menu utama, serta terdapat keterangan dari nama model sambungan, dan jumlah model sambungan yang tersedia, apabila pengguna telah menentukan pilihan model sambungan yang diinginkan, pengguna cukup menekan Button Confirm untuk melanjutkan ke proses modelling. 


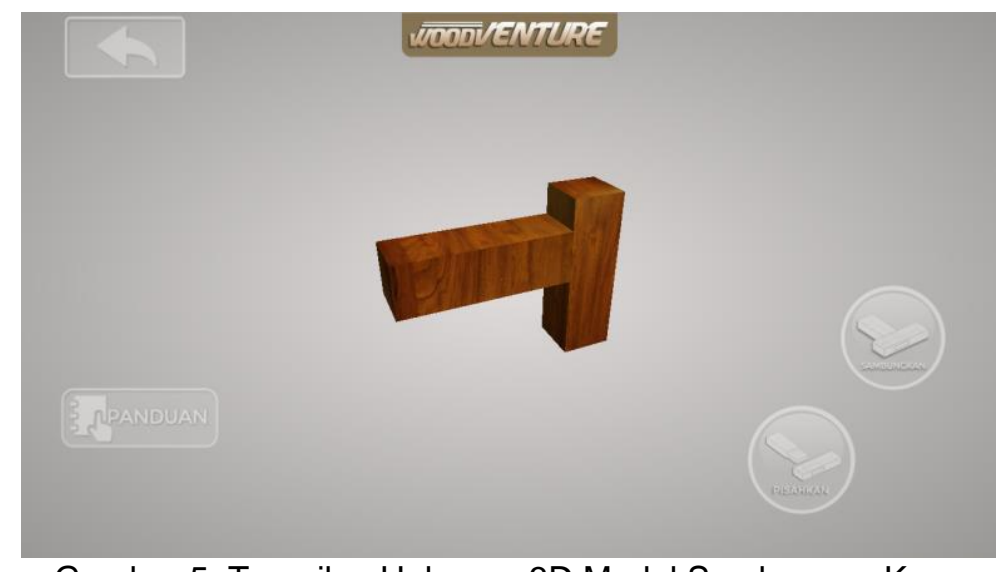

Gambar 5. Tampilan Halaman 3D Model Sambungan Kayu

Tampilan dari Halaman 3D Model Sambungan Kayu yang ditunjukkan Gambar 5 berfungsi untuk menampilkan objek 3D dan animasi model tentang pemasangan sambungan kayu. Fitur yang terdapat pada halaman 3D Model Sambungan Kayu antara lain Fitur Drag, Fitur Scale, dan Fitur Rotate. Beberapa button yang terdapat pada Tampilan Halaman 3D Model Sambungan Kayu diantaranya Button Back, Button Panduan, Button Animasi Pisahkan, dan Button Animasi Sambungkan.

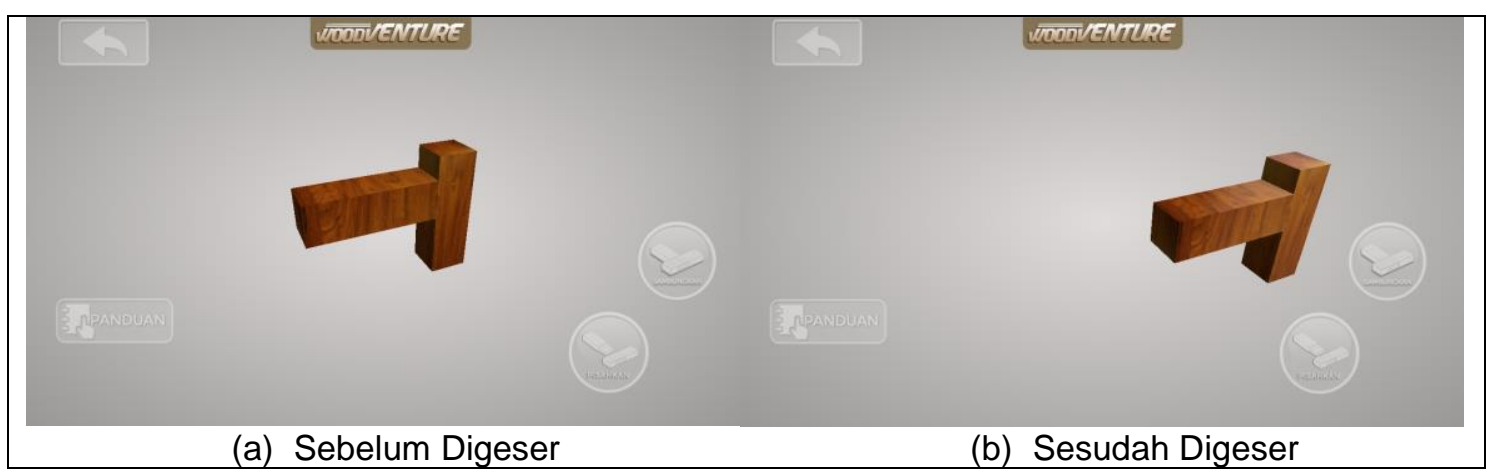

Gambar 6. Tampilan Fitur Drag Aplikasi WoodVenture

Fitur drag dari Aplikasi WoodVenture dapat dilihat pada Gambar 6. Pengguna cukup menekan objek dengan satu jari dan menggeser model sesuai arah yang diinginkan. Fungsi dari fitur drag yaitu untuk menggeser objek ke atas, bawah, kanan, atau kiri. Perbedaan antara Gambar 6a dan Gambar 6b, yaitu objek pada Gambar 6a sebelum digeser sedangkan objek pada Gambar 6b telah digeser ke arah kanan.

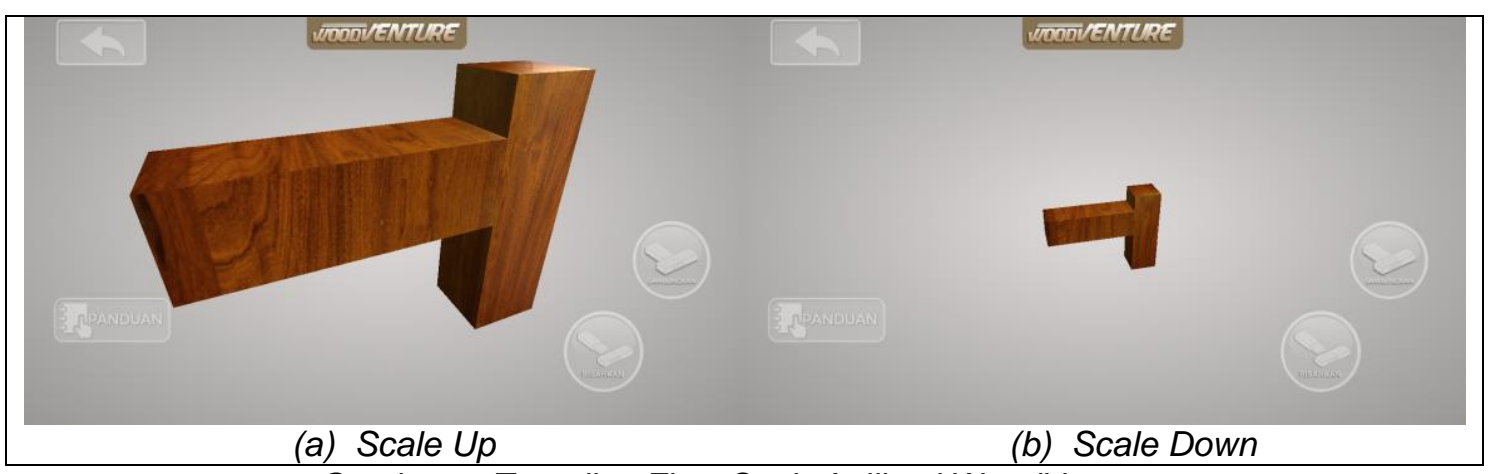

Gambar 7. Tampilan Fitur Scale Aplikasi WoodVenture

Fitur scale dari Aplikasi WoodVenture dapat dilihat pada Gambar 7. Pengguna cukup menekan objek dengan dua jari dan menggeser secara berlawanan arah. Fungsi dari fitur scale yaitu untuk memperbesar ataupun memperkecil objek. Perbedaan yang dapat dilihat pada 
Gambar 7a dan Gambar 7b, yaitu Gambar 7a dilakukan scale up sehingga objek terlihat lebih besar, sedangkan Gambar 7b dilakukan scale down sehingga objek terlihat lebih kecil.

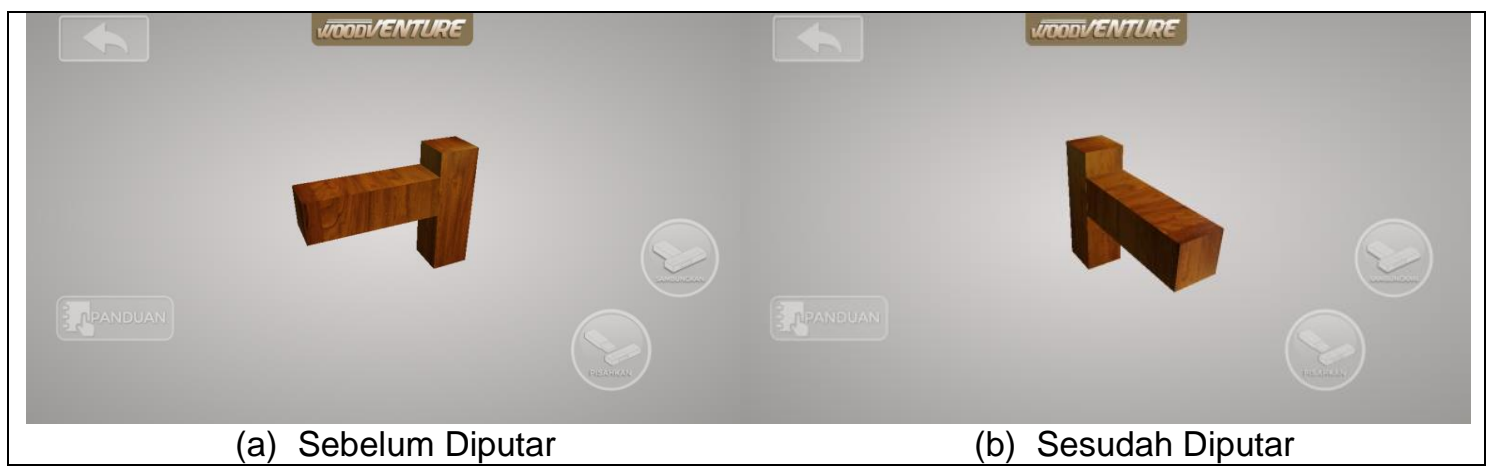

Gambar 8. Tampilan Fitur Rotate Aplikasi WoodVenture

Gambar 8 menunjukkan bahwa fitur rotate pada Aplikasi WoodVenture telah berfungsi. Pengguna cukup menekan objek dengan dua jari dan memutar objek searah jarum jam. Fitur rotate berfungsi untuk memutar model 3D secara 360 derajat. Gambar 8a menunjukkan model 3D sebelum diputar dan Gambar 8b menunjukkan model 3D telah diputar ke arah kanan.

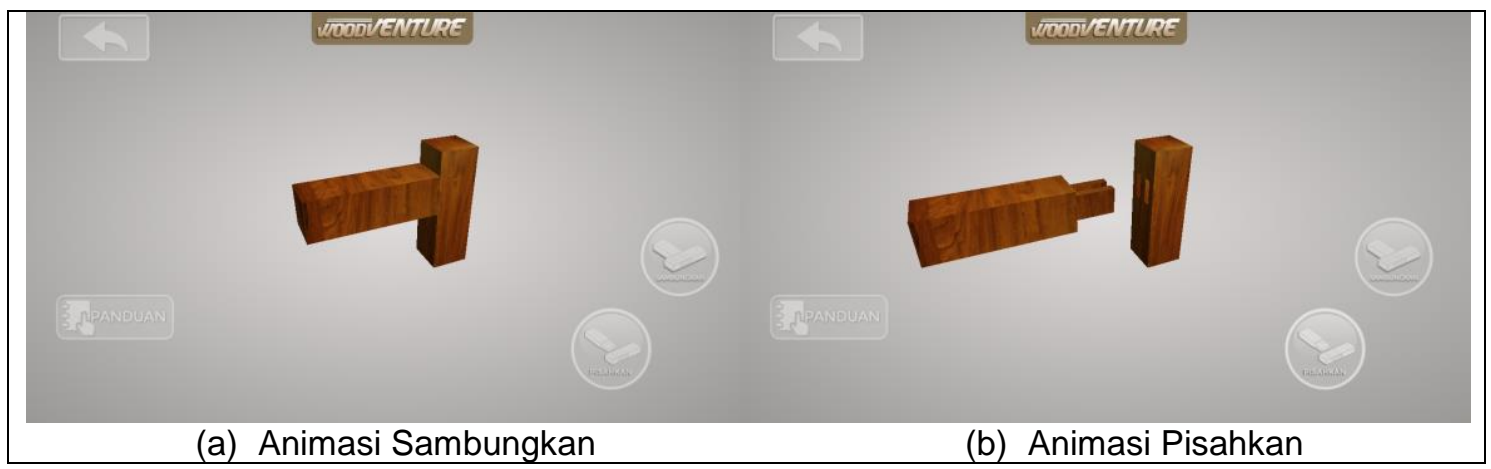

Gambar 9. Tampilan Fitur Animasi Aplikasi WoodVenture

Fitur Animasi dari Aplikasi WoodVenture dapat dilihat pada Gambar 9. Pengguna cukup menekan Button Sambungkan untuk melihat animasi penyambungan objek, dan Button Pisahkan untuk melihat animasi pemisahan objek 3D.

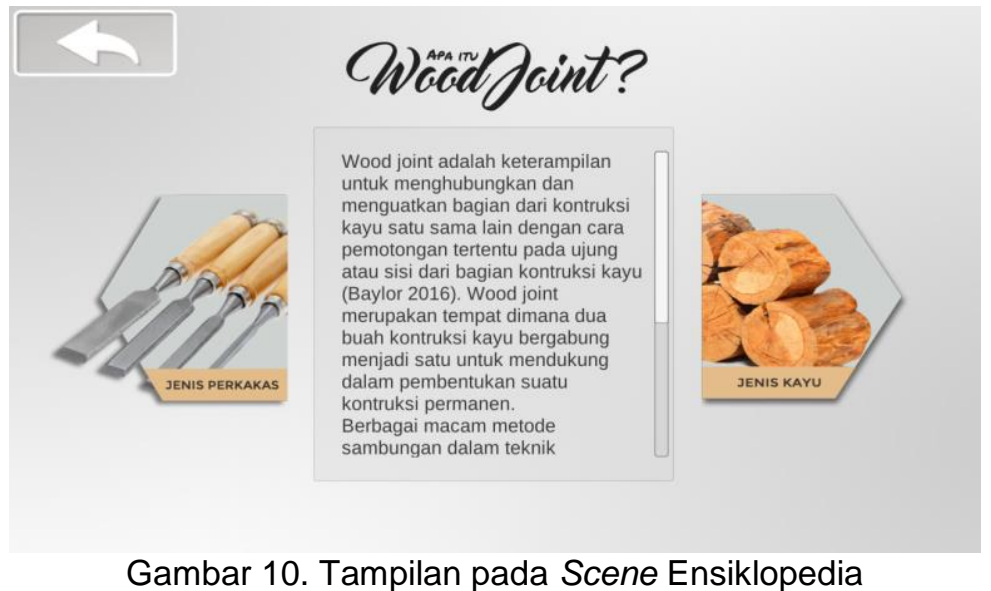

Gambar 10 menunjukkan Tampilan Scene Ensiklopedia pada Aplikasi WoodVenture. Scene Ensiklopedia menyajikan informasi mengenai definisi dari wood joint, dan terdapat dua buah button yang dapat dipilih pengguna untuk mengetahui informasi tentang jenis perkakas ataupun informasi jenis kayu. 


\subsection{Hasil Analisa}

Analisa Rancang Bangun Aplikasi Permodelan Sambungan Kayu (Wood Joint) dengan Objek 3D Berbasis Android menggunakan metode survey, dimana pengambilan data dilakukan dengan menggunakan kuesioner sebagai media survey. Survey melibatkan 50 responden yang terdiri dari masyarakat umum dengan rentang usia $18-56$ tahun.

\subsubsection{Aspek Kebaruan Aplikasi}

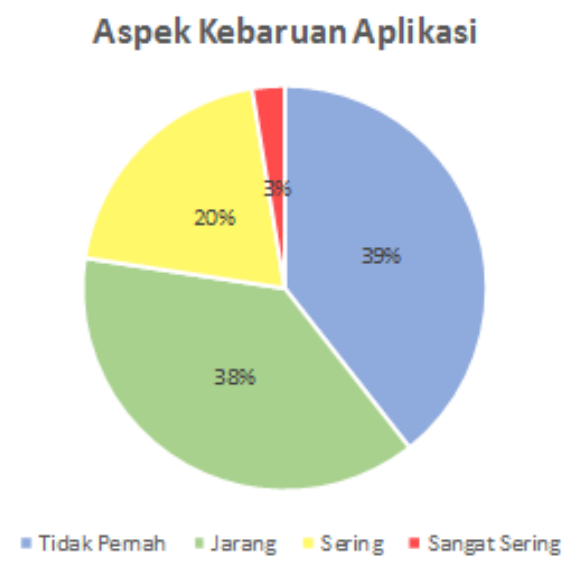

Gambar 11. Diagram Hasil Survey Aspek Kebaruan Aplikasi

Gambar 11 merupakan diagram hasil survey aspek kebaruan aplikasi dari segi pengalaman pengguna mengetahui tentang konsep bermain puzzle dan model sambungan kayu, responden memberikan persentase tertinggi terdapat pada pilihan tidak pernah, sehingga kesimpulan yang dapat diambil dari hasil yang diperoleh adalah responden dapat dikatakan dominan tidak mengetahui aplikasi tentang permodelan sambungan kayu, dan dengan demikian Aplikasi WoodVenture termasuk aplikasi yang baru dalam bidang mebel yang dapat membantu orang awam maupun pengrajin mebel mengetahui tentang permodelan sambungan kayu dalam bentuk model 3D.

\subsubsection{Aspek Grafis Aplikasi}

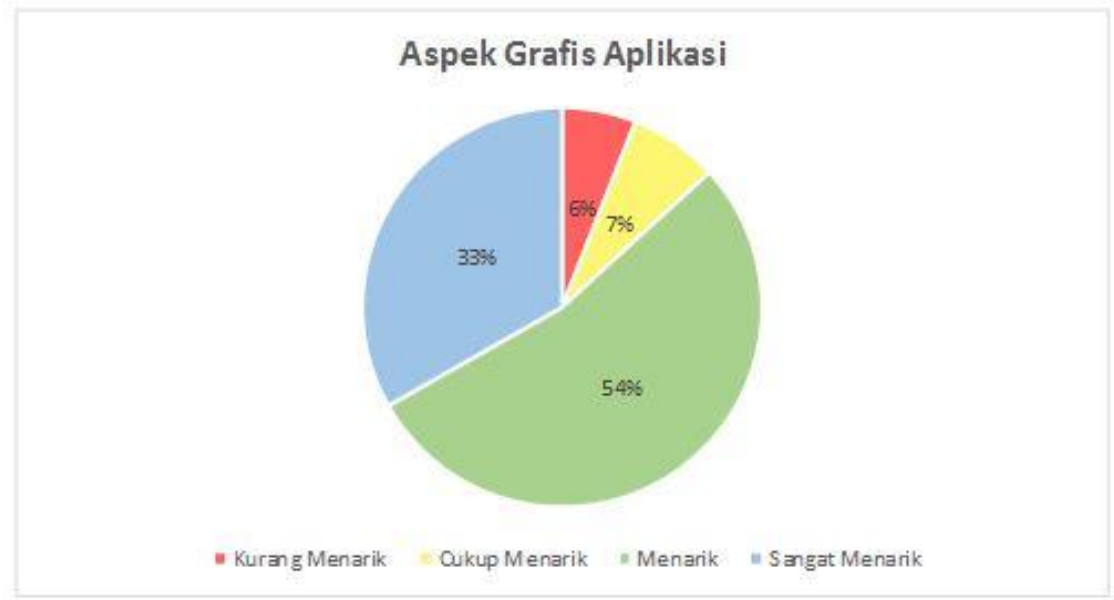

Gambar 12. Diagram Hasil Survey Aspek Grafis Aplikasi

Gambar 12 merupakan diagram aspek grafis aplikasi, responden memberikan persentase tertinggi terdapat pada pilihan menarik, sehingga dapat disimpulkan bahwa grafis dalam hal visual, audio, desain objek, pemilihan font, serta tingkat kemudahan pada Aplikasi WoodVenture menarik bagi pengguna. 


\subsubsection{Aspek Entertainment}

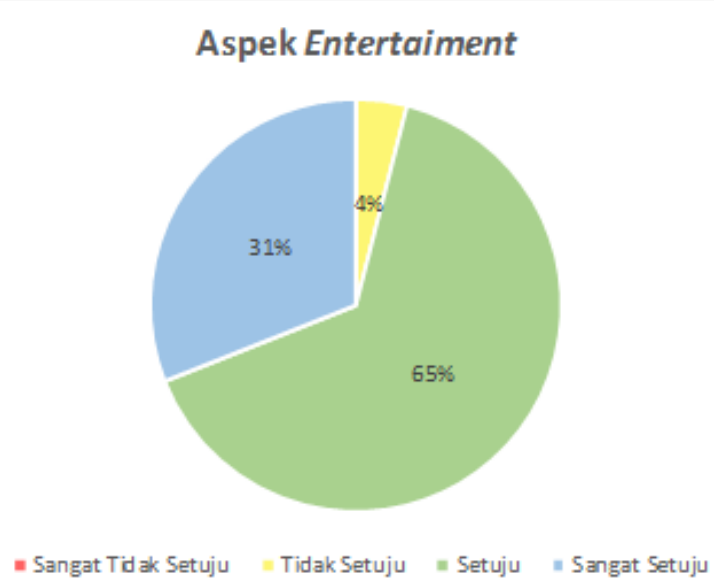

Gambar 13. Diagram Hasil Survey Aspek Entertainment

Gambar 13 merupakan diagram aspek entertainment, responden memberikan respon setuju dengan persentase tertinggi, sehingga dapat disimpulkan bahwa Aplikasi WoodVenture merupakan aplikasi yang menghibur dan menjadi sarana interaktif dalam pembelajaran model sambungan kayu.

\subsubsection{Aspek Content}

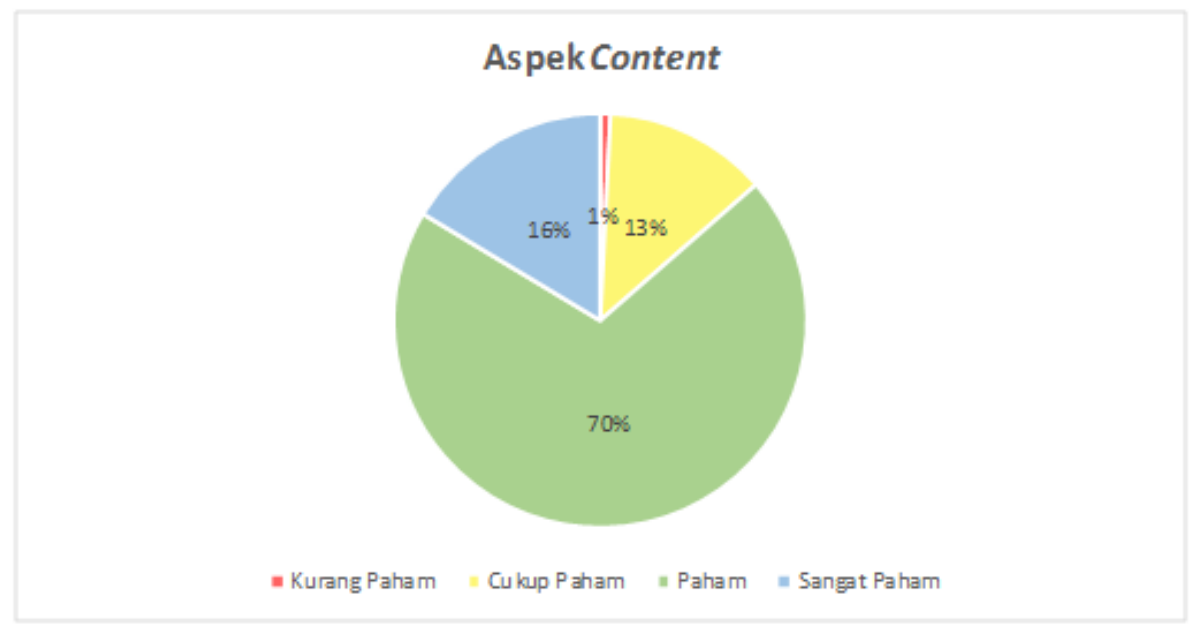

Gambar 14. Diagram Hasil Survey Aspek Content

Gambar 14 merupakan diagram aspek content, sebagian besar responden memberikan respon dengan persentase tertinggi terdapat pada pilihan paham, sehingga dapat disimpulkan bahwa Aplikasi WoodVenture berhasil memberikan pembelajaran dan pemahaman tentang model sambungan kayu disertai pengetahuan tentang jenis perkakas dan jenis kayu.

\section{Kesimpulan}

Aplikasi dikembangkan dengan mengkombinasikan objek 3D dan game engine Unity3D. Model 3D didesain dan divisualisasikan melalui software Blender dengan format file .fbx yang dapat di-import ke dalam game engine Unity3D. Implementasi model 3D dilakukan menggunakan game object yang disesuaikan dengan kebutuhan dalam aplikasi. Game object berperan sebagai wadah atau tempat menampung model sambungan 3D yang telah dibuat, 
sehingga pada model 3D dapat disisipkan fungsi seperti animasi, rotasi, dan penskalaan. Aplikasi WoodVenture memberikan pengetahuan tentang 40 model sambungan kayu melalui fitur animasi penyambungan model 3D, dan terdapat menu pembelajaran yang memuat pengetahuan tentang wood joint, jenis perkakas yang digunakan, serta informasi jenis-jenis kayu yang biasa digunakan dalam kerajinan mebel. Aplikasi yang dihasilkan secara tidak langsung mengedukasi pengguna untuk mengetahui jenis model sambungan kayu yang dibuktikan melalui hasil kuesioner. Kemampuan aplikasi dalam penyampaian pembelajaran ditunjukkan oleh hasil kuesioner yang dilakukan terhadap 50 responden dan mendapatkan hasil paham pada segi content yang mencapai $70 \%$. Hasil dari survey kuesioner memperoleh persentase bernilai menarik pada aspek grafis sebanyak $54 \%$, dan pada aspek entertainment mencapai $65 \%$ dengan nilai setuju. Hasil yang diperoleh pada aspek content, aspek grafis, dan aspek entertainment menunjukkan Aplikasi WoodVenture tergolong baik dari segi grafis, content, dan entertainment sehingga menarik untuk digunakan sebagai sarana pembelajaran mebel bagi masyarakat awam.

\section{Daftar Pustaka}

[1] S. Hajdarević and S. Martinović, "Effect of Tenon Length on Flexibility of Mortise and Tenon Joint," The Journal of Procedia Engineering, vol. 69, pp. 678-685, 2014.

[2] M. G. Arsawiguna, A. A. K. Agung, C. Wiranatha, and K. S. Wibawa, "Rancang Bangun Aplikasi Game Tajen Berbasis Android menggunakan Artificial Intelligence," Lontar Komputer, vol. 6, no. 2, pp. 553-564, 2015.

[3] I. M. W. Saputra, A. A. K. O. Sudana, I. M. Sukarsa, "Information System of Yadnya Ceremony on Android-Based," International Journal of Hybrid Information Technology, vol. 7, no. 6, pp. 155-164, 2014.

[4] A. W. Purnamasari, A. A. K. C. Wiranatha, and N. M. I. M. Mandenni, "Aplikasi MLearning pada Platform Android," Merpati, vol. 2, no. 2, p. 219, 2014.

[5] I. N. A. Wijaya, A. A. K. O. Sudana, and P. W. Buana, "Membuat Ketupat dengan Animasi Model 3D Berbasis Android," Merpati, vol. 4, no. 1, pp. 1-9, 2016.

[6] Wamiliana, D. Kurniasari, and J. S. Nugraha, "Pembuatan Media Pembelajaran Pengenalan Tata Surya dan Exoplanet dengan menggunakan Unity," Komputasi, vol. 1, no. 1 , pp. 47-57, 2013.

[7] A. Nandanwar, M. V. Naidu, and C. N. Pandey, "Development of Test Methods for Wooden Furniture Joints," The Journal of Adhesion, vol. 8, no. 1, pp. 188-197, 2013.

[8] A. A. K. O. Sudana, I. W. M. Sujana, and N. K. D. Rusjayanthi, "Arbantenotonan: A Learning Media Base on Augmented Reality Traditional Balinese Birthday Ceremony Equipment," Journal of Theoretical and Applied Information Technology, vol. 95, no. 7, pp. 1362-1369, 2017.

[9] I. D. M. Y. A. Putra, A. A. K. A. C. Wiranatha, and P. W. Buana, "Rancang Bangun Game Tapel Bali pada Platform Android," Lontar Komputer, vol. 6, no. 1, pp. 1-12, 2015.

[10] R. H. Craighton, Unity 3D Game Development by Example. Birmingham: Packt Publishing, 2011. 